\title{
The Use of Floating Solar Panels in Hot Regions Such as Iraq to Benefit in Cooling the Panels and Increasing Their Efficiency
}

\author{
Ahmed Z. Abass \\ Industrial Power Supply Systems \\ Ph.D \\ Novosibirsk, Russia \\ ORCID: http://orcid.org/ 0000-0003-1836-3435, theking.amir@mail.ru \\ D.A Pavlyuchenko \\ Industrial Power Supply Systems \\ Ph.D., Associate Professor \\ Novosibirsk, Russia \\ ORCID: https://orcid.org/0000-0003-4522-9557, pavlyuchenko@corp.nstu.ru
}

\begin{abstract}
The operating of photovoltaic panels (PV) comes with a serious contradiction. This system of solar PV panels prefers high radiation to generate electricity, but when rising their operating temperature by negative effects on their efficiency. Thus, one of the major working barriers for PV panels is overheating because of surplus solar irradiation. To get rid of the problem of overheating of the panels, we propose a new design that floats on the surface of the water floating photovoltaic panels (FPV) to take advantage of the nature of water in heat transfer, thus cooling the panels and raising the efficiency of the panels. For the purpose of this study, we proposed one of the regions of central Iraq, namely the Marsh Al-Dalmach, which is located in Wasit province, and it is one of the areas rich in solar radiation $(2150 \mathrm{kWh} / \mathrm{m} 2 /$ year $)$ and the length of daylight hours more 4000 operating hours during the year. After conducting a survey around the area and collecting the necessary data for use in programs such as Homer and Matlab, great results were obtained, as this design of the stations contributes to reducing temperatures and raising the efficiency of the panels from $15 \%$ to $24 \%$.
\end{abstract}

Keywords- Renewable energy; solar energy; floating PV; improving efficiency; eco-friendly.

\section{INTRODUCTION}

Electric energy is a wide field currently suffering from many challenges, from developing connect to electricity and grid connection, to climate change reduction and shifting to renewable energy solutions like solar and wind energy. However, the current electric energy systems around the world have been described as unsustainable and dangerous, leading to inequalities, human conflicts, and natural disasters because of the daily burning of a huge amount of fossil fuel. Through the last decades, many conferences at international and national levels have been taking place around the world, to find cleaner and efficient solutions, lead and influenced by the United Nations and some major international agencies like IRENA
(International Renewable Energy Agency) and IEA (International Energy Agency)[1]. Many countries have begun to gather and set ambitious aims for enhancing the use of clean energy. Solar energy is one of the most promising renewable technologies proposed, because solar energy is the most abundant resource in the world, so encouraging the use of technical solutions to transform this energy in an efficient method. Among these solar energy technologies, the fastestgrowing solution is solar PV panels. This increase is mainly because of the high decline of modules PV prices, which constitutes the PV panels systems investments, together with ambitious government incentives. Offering utility-scale and cost-effective installations, large-scale solar PV plants are absolutely in the scope of project investments. However, 
building large-scale PV plants needs vast land availability, while many countries suffer land shortage. In a sustainable economy, the lands play a critical role in farming or any other economic activities. In many time, implementations of solar PV project suffer land problems like land purchase or substation availability and sizes. If the projects are planned in large remote areas, increasing investments costs for electricity transmission. Furthermore, solar PV plant operation is strongly affected by temperature. When the temperature increases, the output power of the PV panel decreases as a result, due to absorption of PV modules including an increase of the module temperature. A large interest has grown to control rising temperature variations. So, efficiency enhancements for solar PV are key to raise the viability of the solar technologies. For control these critical problems, a new method has come in front and suggest to install solar PV panels on water surface by using floating structures. Floating solar concept are specially interesting for the countries with irregular land, like mountainous or coastal lands, in addition with very high population and activities density or countries with the arid climate [2,3]. Furthermore, the PV panels fixed on a floating structure are dependent to natural convection because of the lower temperature of water. The large availability of water is a very good parameter when need thinking about use cooling methods. Thus floating solar way have great chance in hot and arid countries like Iraq, where operating temperature need to be controlled to optimize panel execution [4].

\section{WHY FLOATING SOLAR SYSTEM}

The first floating solar system was installed in 2007 in California (USA). Today, system floating solar market is mostly active in the Asian countries (Japan, China, Korea), Ciel $\&$ Terre is considered one of the best companies in this field, as it has implemented many projects around the world [5]. Japan was the first country in Asia that large-scale floating power plants were installed and connected, with total capacity 60 MWp. The wide land use of installed ground-mounted solar system large-scale PV system can be partly averted by using the new method of floating solar system on water surface. It is perfect in countries with nonflat land, mountains areas, hot and arid weather, and very often unused water areas. Use of floating solar plant comes with a various of water forms:

Marshes and lakes, industrial water ponds, centers for water handling, reservoirs for retention and irrigation, water surfaces for drinking, quarry and hydroelectric dams, aquaculture farms. When using floating solar plant have many benefits like [6]:

- Reduce evaporation of water, and help to preserves existing ecosystems and smoothest development process;

- Minimize erosion of reservoirs and any metallic figures by decreasing wave movements.

- Minimize algal bloom and water hyacinths;

- Turned this unused space (water bodies) into useful

area;

- Minimizes costs of grid-connection that enjoying existing electrical infrastructures;

- Increases electricity production due to water natural passive cooling affect;

- $\quad$ Save useful land for agriculture or any other usage and rehabilitated polluted areas by generating clean energy.

\section{PHENOMENON CONTINENTALITY}

Air temperature is highly effected by the position of a place close to a large body of water like seas, marshes, lakes, etc.
This impact of location on weather quality of a place is named phenomenon (continentality). The temperature of air close or over bodies of water is more different from that over land because of variations in the method of water and land heat and cool. Characteristics that effect water temperature are [7]:

Transparency of water;

Allocation of $\mathrm{Q}^{*}$;

The power of water circulating;

Specific water heat.

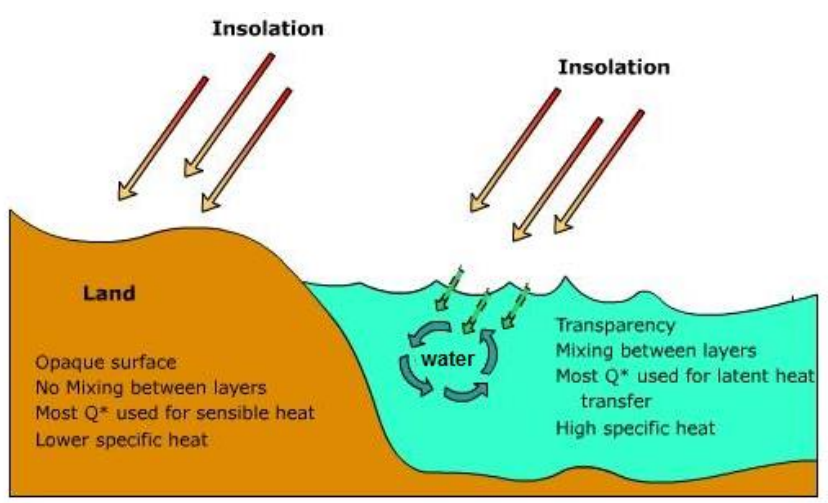

Fig.1. Phenomenon continentality

The water is a transparent environment and the land is non transparent (opaque). The water permits light to penetrate to bottom, leaving surface water layers more cooler than they would be if the surface was opaque. The cooler water surface due to cooled air temperatures above. If the solar radiation falls on land, this fallen energy is absorbed by a thin layer and heats rapidly. Also, it easy gives up its heat to the ambient atmosphere. When the fallen insulation energy is absorbed by the land, most of the radiation is utilized for the sensible heat transfer or the ground heat transfer, only small amounts are used for latent heat transfer. As sensible heat transfer into the atmosphere is the predominant heat transfer, thus air temperatures rises over the land. on the other hand, over the water, much of the net irradiation is used for the evaporation water. Thus, few energies utilized for sensible heat transfer, so atmosphere over water stay cooler than that over land. Water is capable to in freeway circulate, because of being fluid. The water surface that has been heated by the sun can blend with the cooler water at bottom, so protection the water cool. The land cannot circulate heated surface layers with cooler ones below, thus rise surface land temperatures and higher atmosphere temperatures than these above the water. Specific heat of the water is more than of the land. The water has a specific heat higher than that land in 5 times. That means the water takes 5 times more energy to heat 1 gram than 1 gram of land. Thus if close land (coast) and water accept the same quantity of irradiation, water will heat more slower than the land, and give up part of its heat high slowly than the land. To understand this, we conducted a simple experiment in Wasit province, which is located in the center of Iraq, by comparing temperatures throughout the year between one of the marshes in the city (Dalmach marsh)[8], its coast, and the city in general, and illustrated in the figure 2. 


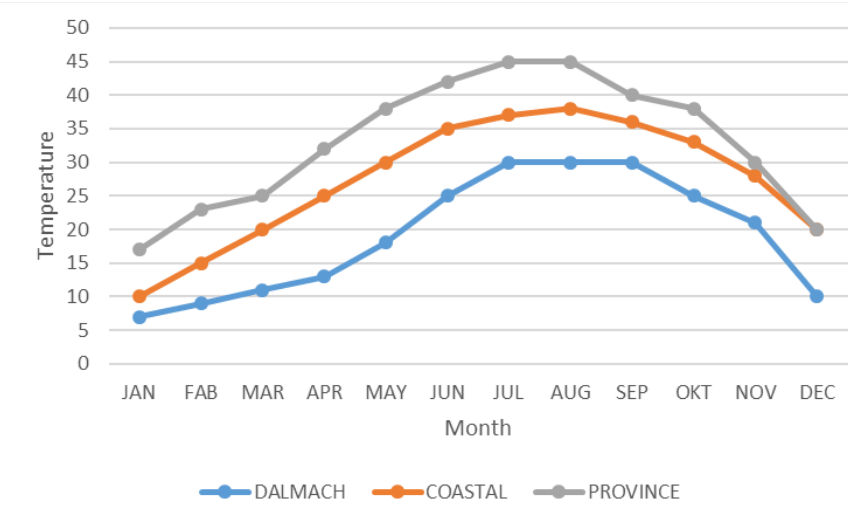

Fig.2. Comparison temperatures (marsh, coast, city)

Resulting, air temperatures are always lower above the water surface than above neighboring land. When this cooler air comes coast, air temperatures above the land will be decreased. As the water's temperature doesn't change (fluctuate) as such as that of the land, temperature ranges are minimal above the water and coastal locations than those in the city [9].

\section{CONCEPT FLOATING SYSTEM (FPV)}

The major problem with photovoltaic panel is its relatively small efficiency. More available photovoltaic panels succeed to convert only $8 \%-18 \%$ of the fallen irradiation on them into electrical energy. The best execution by a photovoltaic panel is reported by Sharp company at $1000 \mathrm{~W} / \mathrm{m}^{2}$, for a surface temperature of $25^{\circ} \mathrm{C}$, thus the efficiency will decrease by 0.485 $\%$ per $1{ }^{\circ} \mathrm{C}$ temperature rise. To eliminate the problem of overheating of solar panels, we offer this design to operate at appropriate temperatures, which contributes to increasing the efficiency of solar panels and increases the amount of energy produced [10]. The design illustrated by Fig.3.

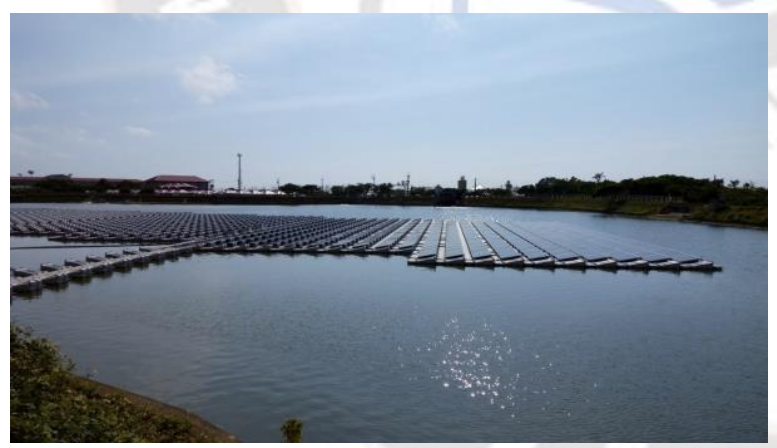

Fig.3. floating system (FPV)
The FPV system connected in a similar way as the standard ground-mounted PV system in the utility-scale station, when FPV modules are linked in series to make strings, and strings are then collected to make solar arrays. Electrical designing is creating to volume (strings $\&$ arrays) so as to obtain voltage and current demands of the array. FPV system contains of PV panels fixed on a floating body, consist of several floats jointed with each other. Floating platform is made of fundamental float structures, bearing PV panels, and secondary float body's utilized for servicing, and keeping distance between PV panels. The best material for float body are made of high density polyethylene, and are linked together by connection pins. The optimum tilt angle for city is fixed on $31^{\circ}$ [11]. The fundamental float is prepared with a hole in the center, this hole for passively cooling and for ventilating PV panels. All PV modules are fixed to the floats structure through aluminum rails, depending on the structure modules size.

\section{CASE STUDY: IRAQ/ MARSH DALMACH}

Marsh Al-Dalmach or Hor Afak is a large water body in Iraq that feeds from the general downstream drainage between the Tigris and the Euphrates, and is located between provinces Diwaniyah to the west and Wasit to the east with area about 120,000 dunum $\left(300,000,000 \mathrm{~m}^{2}\right)$ [12]. Iraq is a region rich in solar energy, where the sun's brightness increases more than 4000 hours a year $[13,14]$. In this paper, we will study the effect of temperature on the performance of solar panels and choose the marsh area in order to take advantage of the breeze phenomenon or (continentality). The region is very rich in solar radiation throughout the year, as well as the length of daylight hours, but the only problem is the high temperatures and these figures $(4,5,6)$ and table1 illustrate that. Important data about the area were collected with the help of the services provided by NASA and this data is very important for conducting the study using important programs such as Homer and Matlab.

TABEL1. SOLAR RADIATION IN MARSH DALMACH FOR YEAR [15,16]

Parameter(s):

\section{DNR_MAX SRB/FLASHFlux 1/2x1/2 Maximum Direct Normal Radiation (kW-hr/m^2/day)}

DNR_MIN SRB/FLASHFlux 1/2x1/2 Minimum Direct Normal Radiation (kW-hr/m^2/day)

DNR SRB/FLASHFlux 1/2x1/2 Direct Normal Radiation (kW-hr/m^2/day)

\begin{tabular}{|l|l|l|l|l|l|l|l|l|l|l|l|l|l|l|l|}
\hline LAT & LON & PARAMETER & JAN & FEB & MAR & APR & MAY & JUN & JUL & AUG & SEP & OCT & NOV & DEC & ANN \\
\hline $\mathbf{3 2 . 2 5}$ & $\mathbf{4 6 . 2 5}$ & DNR & 5.16 & 5.8 & 5.51 & 5.49 & 6.75 & 8.66 & 8.1 & 7.64 & 6.9 & 4.8 & 4.14 & 4.46 & 6.12 \\
\hline $\mathbf{3 2 . 2 5}$ & $\mathbf{4 6 . 2 5}$ & DNR_MAX & 6.27 & 7.85 & 7.11 & 6.72 & 8.37 & 10.74 & 9.6 & 8.65 & 7.83 & 5.87 & 4.98 & 5.17 & 7.43 \\
\hline $\mathbf{3 2 . 2 5}$ & $\mathbf{4 6 . 2 5}$ & DNR_MIN & 3.59 & 4.2 & 4.45 & 4.04 & 5.64 & 6.48 & 6.12 & 6.61 & 5.32 & 3.87 & 3.34 & 3.2 & 4.74 \\
\hline
\end{tabular}




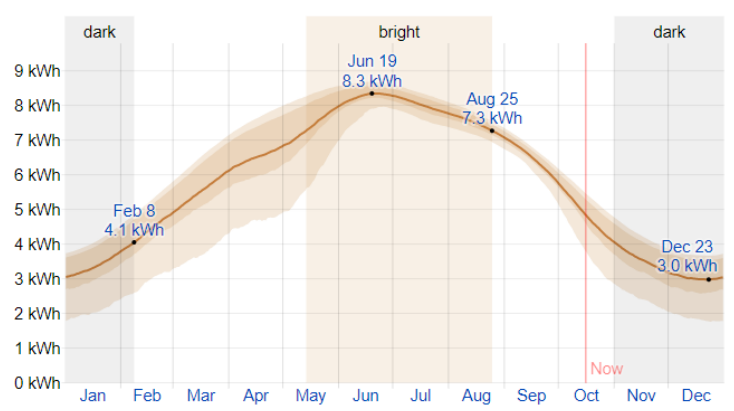

Fig.4. Average radiation in marsh Dalmach

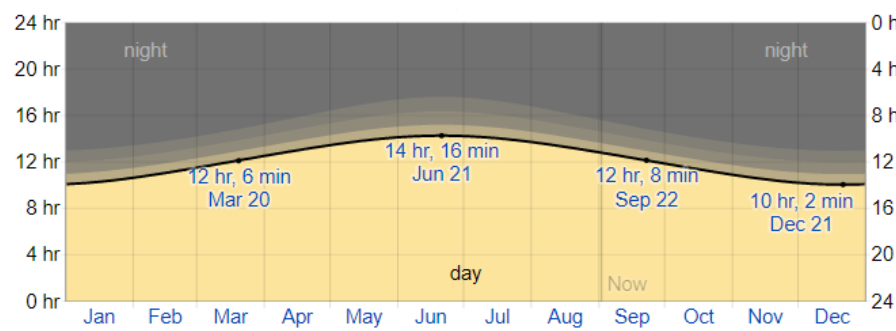

Fig.5. Average daylight through the year

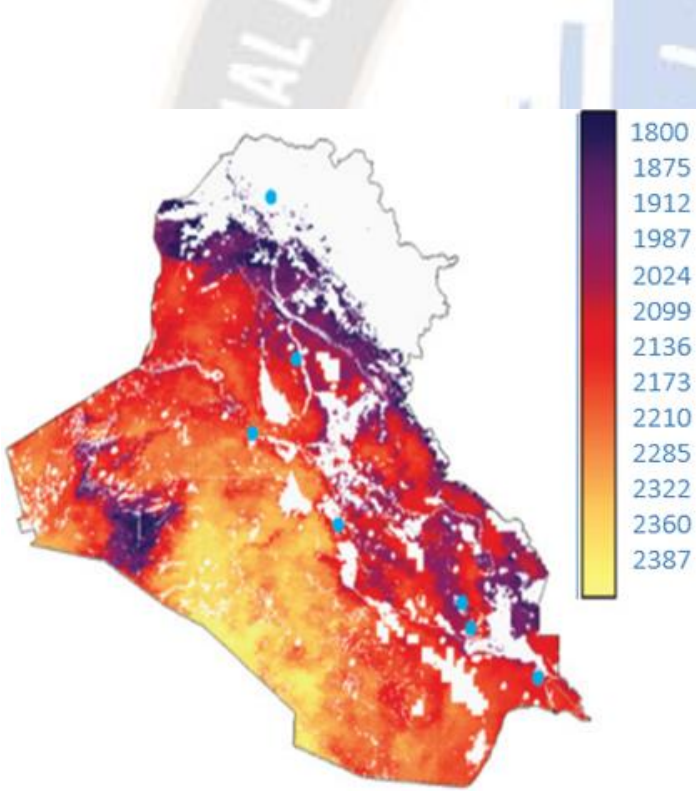

Fig. 6. Annual Solar radiation in Iraq

\section{RESULT AND DISSECTION}

As we mentioned, experimental results were obtained by helping the programs Homer and Matlab. The results show the increase of power produced by the solar panel when floating on water with the heat sink at the panels back. This experiments were done on three separate places during which the solar radiation should be the same, and fluctuation of temperature are different according to phenomenon's continentality and breeze. The proposed plant occupies about 5,000 $\mathrm{m}^{2}$.

A. First case when the plant in the city at normal structure without any cooling system with efficiency $15 \%$, the energy produced over year about $1209 \mathrm{MWh} /$ year. The results illustrated in table 2 .
TABLE 2. THE RESULTS AT CASE NORMAL DESIGN IN CITY $[17,18]$

\begin{tabular}{|c|c|c|}
\hline Parameters & Amount & Unit \\
\hline $\mathrm{E}=$ Energy produced $(\mathrm{kWh})$ & 1208640 & $\mathrm{kWh} / \mathrm{an}$ \\
\hline $\mathrm{A}=$ Total solar panel Area $\left(\mathrm{m}^{2}\right)$ & 5000 & $\mathrm{~m}^{2}$ \\
\hline $\mathrm{r}=$ solar panel yield $(\%)$ & $15 \%$ & \\
\hline $\begin{array}{l}\mathrm{H}=\text { Annual average irradiation on tilted } \\
\text { panels (shadings not included) }\end{array}$ & 2150 & $\mathrm{kWh} / \mathrm{m}^{2} \cdot \mathrm{an}$ \\
\hline $\begin{array}{l}\mathrm{PR}=\text { Performance ratio, coefficient for losses } \\
\text { (range between } 0.9 \text { and } 0.5 \text {, default value }= \\
0.75 \text { ) }\end{array}$ & 0.75 & \\
\hline \multicolumn{3}{|c|}{ Losses details (depend of site, technology, and sizing of the system) } \\
\hline Inverter losses $(6 \%$ to $15 \%)$ & $8 \%$ & \\
\hline Température losses (5\% to $15 \%)$ & $8 \%$ & \\
\hline DC cables losses ( 1 to $3 \%)$ & $2 \%$ & \\
\hline AC cables losses ( 1 to $3 \%)$ & $2 \%$ & \\
\hline Shadings $0 \%$ to $40 \%$ & $3 \%$ & \\
\hline Losses weak irradiation $3 \%$ yo $7 \%$ & $3 \%$ & \\
\hline Losses due to dust, snow... (2\%) & $2 \%$ & \\
\hline Other Losses & $0 \%$ & \\
\hline
\end{tabular}

B. This case when plant at coast region, in this case, the station benefits from the phenomenon of the breeze and helps in cooling the panels and raises the efficiency of the panels to $18 \%$, and the plant can increase the produced energy to 1450 $\mathrm{MWh} /$ year. The results illustrated in table 3.

TABLE 3. THE RESULTS AT COASTAL REGION WITH NORMAL DESIGN

\begin{tabular}{|l|r|l|}
\hline \multicolumn{1}{|c|}{ Parameters } & Amount & Unit \\
\hline $\mathrm{E}=$ Energy produced (kWh) & 1450368 & $\mathrm{kWh} / \mathrm{an}$ \\
\hline $\mathrm{A}=$ Total solar panel Area $\left(\mathrm{m}^{2}\right)$ & 5000 & $\mathrm{~m}^{2}$ \\
\hline $\mathrm{r}=$ solar panel yield (\%) & $18 \%$ & \\
\hline $\begin{array}{l}\text { H = Annual average irradiation on tilted panels } \\
\text { (shadings not included) }\end{array}$ & 2150 & $\mathrm{kWh} / \mathrm{m}^{2} . \mathrm{an}$ \\
\hline $\begin{array}{l}\text { PR = Performance ratio, coefficient for losses } \\
\text { (range between 0.9 and 0.5, default value } \\
0.75)\end{array}$ & 0.75 & \\
\hline Losses details (depend of site, technology, and sizing of the system) \\
\hline Inverter losses (6\% to 15\%) & $8 \%$ & \\
\hline Température losses (5\% to 15\%) & $8 \%$ & \\
\hline DC cables losses (1 to 3\%) & $2 \%$ & \\
\hline AC cables losses (1 to 3\%) & $2 \%$ & \\
\hline Shadings 0 \% to 40\% & $3 \%$ & \\
\hline Losses weak irradiation 3\% yo 7\% & $3 \%$ & \\
\hline Losses due to dust, snow... (2\%) & $2 \%$ & \\
\hline Other Losses & $0 \%$ & \\
\hline
\end{tabular}

C. This case when using FPV system over marsh Dalmach, in this design, the plant takes advantage of the phenomenon of the continentality and helps in cooling the panels and raises the efficiency of the panels to $24 \%$, and the proposal produced energy about $1934 \mathrm{MWh} /$ year, the results illustrated in table 4. 
International Journal on Recent and Innovation Trends in Computing and Communication

ISSN: 2321-8169 Volume: 8 Issue: 10

DOI: https://doi.org/10.17762/ijritcc.v8i10.5446

Article Received: 25 August 2020 Revised: 14 September 2020 Accepted: 28 September 2020 Publication: 31 October 2020

TABLE 4. THE RESULTS BY USING FPV AT MARSH DALMACH

\begin{tabular}{|l|r|l|}
\hline \multicolumn{1}{|c|}{ Parameters } & Amount & Unit \\
\hline $\mathrm{E}=$ Energy produced $(\mathrm{kWh})$ & 1933824 & $\mathrm{kWh} / \mathrm{an}$ \\
\hline $\mathrm{A}=$ Total solar panel Area $\left(\mathrm{m}^{2}\right)$ & 5000 & $\mathrm{~m}^{2}$ \\
\hline $\mathrm{r}=$ solar panel yield $(\%)$ & $24 \%$ & \\
\hline $\begin{array}{l}\mathrm{H}=\text { Annual average irradiation on tilted } \\
\text { panels (shadings not included) }\end{array}$ & 2150 & $\mathrm{kWh} / \mathrm{m}^{2} \cdot \mathrm{an}$ \\
\hline $\begin{array}{l}\text { PR = Performance ratio, coefficient for } \\
\text { losses (range between 0.9 and 0.5, } \\
\text { default value = 0.75) }\end{array}$ & 0.75 & \\
\hline
\end{tabular}

Losses details (depend of site, technology, and sizing of the system)

Inverter losses (6\% to $15 \%)$

Température losses (5\% to $15 \%)$

DC cables losses (1 to $3 \%$ )

AC cables losses (1 to $3 \%)$

Shadings $0 \%$ to $40 \%$

Losses weak irradiation $3 \%$ yo $7 \%$

Losses due to dust, snow... (2\%)

Other Losses

From these results it is clear that this is the best design that can be used to reduce the impact of high temperatures and raise the efficiency of solar panels, as there is an increase from $15 \%$ to $24 \%$ in this experiment between the three places. And by using Matlab and re-experimenting on one plate and at different temperatures, we get the following result, which is shown in the figure 7 .
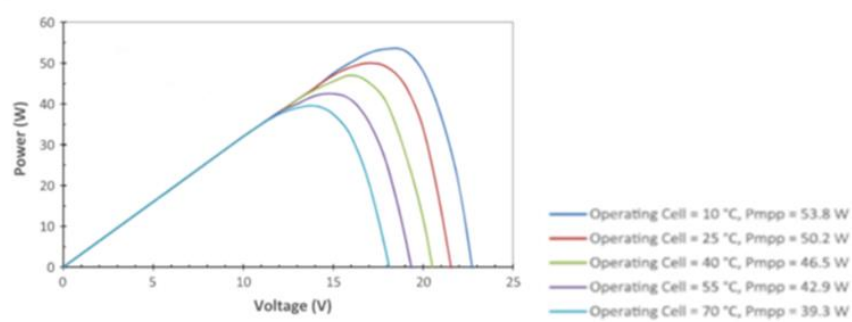

Fig. 7. Impact of temperature on power output

It is clear from the figure that the power produced and the voltage increases as the temperature decreases, as the experiment was conducted on 5 different temperature regions and with the same solar panel.

\section{CONCLUSION}

For decades, Iraq suffers from a severe shortage of electricity supply, especially in poor rural areas. In this study, we chose the Dalmach area, as it is an agricultural area and many farmers live in it near the marsh, as it is a source of fresh water and can be used for irrigation of agricultural lands. Because of the high temperatures, large quantities of water evaporate, which leads to an increase in the salinity of the water, so we suggested using this design of the stations to cover about $50 \%$ to $70 \%$ of the marsh area to reduce the percentage of evaporated water and to take advantage of the phenomenon continentality to raise the efficiency of solar panels and in addition to other benefits which mentioned in paragraph II.

\section{REFERENCES}

[1] International Renewable Energy Agency, https://www.irena.org/

[2] Antoine Dizier, "Techno-economic analysis of floating PV solar power plants using active cooling technique", Master of Science Thesis TRITA-ITM-EX, 2018:678.

[3] Z. A. A. Majid1, M. H. Ruslan2, K. Sopian3, M. Y. Othman4, M. S. M. Azmi5," study on performance of 80 watt floating photovoltaic panel", Journal of Mechanical Engineering and Sciences (JMES) ISSN (Print): 2289-4659; e-ISSN: 2231-8380; Volume 7, pp. 1150-1156, December 2014.

[4] Abass Ahmed Z., Pavlyuchenko D.A. Southern Iraq gas station conversation to integrated solar combined cycle / E3S Web of Conferences 114, 05008 (2019). Energy Systems Research 2019. https://doi.org/10.1051/e3sconf/201911405008 .

[5] Ciel \& Terre company, https://www.ciel-et-terre.net/ .

[6] Ahmed Zkear Abass, Pavlyuchenko D.A. The exploitation of western and southern deserts in Iraq for the production of solar energy / International Journal of Electrical and Computer Engineering 9(6), 2019, p. 4617-4624, DOI: 10.11591/ijece.v9i6.pp4617-4624 .

[7] Muhammad Sohail Gadiwala ${ }^{1}$, Farkhunda Burke², Muhammad Touseef Alam3, Syed Nawaz-ul-Huda4, Muhammad Azam5, "Oceanity and continentality climate indices in Pakistan", GEOGRAFIA OnlineTM Malaysian Journal of Society and Space 9 issue $4(57$ - 66) 57 (C) 2013, ISSN 2180-249. https://www.researchgate.net/publication/280037748_Oceanity_a nd_continentality_climate_indices_in_Pakistan .

[8] Mesopotamian Marshes, Wikipedia, the free encyclopedia," https://en.wikipedia.org/wiki/Mesopotamian_Marshes “.

[9] Iraqi meteorological organization and seismology, http://meteoseism.gov.iq/index.php .

[10] PV magazine, https://www.pvmagazine.com/2020/03/31/cooling-down-pv-panels-with-water/ .

[11] Akeel M. Ali Morad, Ali K. Shaker Al-Sayyab*, Mohammed A. Abdulwahid," Optimisation of tilted angles of a photovoltaic cell to determine the maximum generated electric power: A case study of some Iraqi cities", Case Studies in Thermal Engineering 12 (2018) 484-488.

[12] Wikipedia, the free encyclopedia https://ar.wikipedia.org/wiki/\%D9\%87\%D9\%88\%D8\%B1_\%D8 \%A7\%D9\%84\%D8\%AF\%D9\%84\%D9\%85\%D8\%AC .

[13] Abass A.Z., Pavlyuchenko D.A., Balabanov A.M., Less V.M. Inclusion of solar energy in iraq gas-turbine power plants as a method of solving the country's energy system shortage. Power engineering: research, equipment, technology. 2020;22(2):98107. (In Russ.) https://doi.org/10.30724/1998-9903-2020-22-198-107.

[14] Ahmed Z. Abass 1, D.A Pavlyuchenko2, I.V. Kobobel3, solar energy perspectives in Iraq, Power engineering: research, equipment, technology. 2020 (45); pp 63-70.

[15] The Typical Weather Anywhere on Earth, https://weatherspark.com/ .

[16] NASA The Prediction Of Worldwide Energy Resources (POWER), https://power.larc.nasa.gov/\#page-top.

[17] HOMER pro

3.11 , https://www.homerenergy.com/products/pro/docs/3.11/index.html [18] PV watts calculator, [Online]. Available: https://pvwatts.nrel.gov. 